\title{
淀川・大和川における水質モニタリング指標を 用いた物質輸送量の推定 \\ ESTIMATION OF MATERIAL LOADINGS UTILIZING AUTOMATIC MONITORING DATA IN THE YODO RIVER AND THE YAMATO RIVER
}

\author{
中谷祐介 1 - 今岡知武 $2 \cdot$ 西田修三 3 \\ Yusuke NAKATANI, Tomotake IMAOKA and Shuzo NISHIDA \\ 1 学生会員 修 (工) 大阪大学大学院 工学研究科地球総合工学専攻（广565-0871 吹田市山田丘2-1） \\ 2学生会員 学 (工) 大阪大学大学院 工学研究科地球総合工学専攻（广565-0871 吹田市山田丘2-1) \\ 3 正会員 工博 大阪大学大学院教授 工学研究科地球総合工学専攻（广565-0871 吹田市山田丘2-1）
}

\begin{abstract}
During flood periods, rivers transport large amounts of water and nutrient loads, and have significant impacts on water quality and ecosystems in enclosed waters. In this study, observations were carried out in the Yodo River, the three upstream rivers (the R. Katsura, the R. Uji, and the R. Kizu), and the Yamato River in ordinary and flood conditions. As a result, the relationships of SS with PN, PP, and POC were formulated, and we could estimate the loading amounts of PN, PP, and POC, using these correlations and the turbidity measured by automatic monitoring system. In a similar way, from the monitoring electric conductivity data, the loading amounts of DIN and $\mathrm{PO}_{4}-\mathrm{P}$ were estimated with a high degree of accuracy in the Katsura River, where the water quality was influenced strongly by point source pollution.
\end{abstract}

Key Words : Yodo River, Yamato River, Flood, Automatic monitoring data, Nutrients

\section{1. はじめに}

閉鎖性水域の水環境に及ぼす出水のインパクトは大き く，その影響を精確に評価することは水質管理の観点か ら重要である11. 近年は出水時負荷の重要性についての 認識が高まり, 各水域を対象に多くの研究が進められつ つある2,3)。これまで筆者らは，大阪湾主要流入河川であ る淀川や大和川において平水時および出水時に現地観測 を実施し，流入負荷の実態把握に向けたデータの蓄積と 解析を進めてきた (4),5), . その結果, 物質負荷量と河川流 量の関係（L-Q関係）は高流量域において大きく散乱す ることが明らかになった，その原因として，増水期と減 水期に生じるヒステリシス効果をL-Q式では反映できな いこと，また複数の上流支川を有する場合には各支川の 流出特性が異なるために, 流域内の降雨パターンにより 合流部下流の水質が大きく左右されること等が挙げられ る.これらのことから，L-Q式を用いて流量データのみ から負荷量を精確に推定することには限界があると考え られる.

一方で, 我が国の主要河川では自動観測機器を用いた 流況・水質モニタリングが行われており, 水位, 水温,
$\mathrm{pH}, \mathrm{DO}, \mathrm{COD}$, 濁度, 電気伝導度 (以下, 電導度) 等 について短時間隔の詳細な連続データを利用することが 可能である. しかし, 観測センサ一機器や組み込み可能 な分析システムによる計測はなされているものの, 水環 境の解析において重要となる栄養塩類のモニタリングは 十分にはなされていない. 現地設置型の自動分析装置を 用いた栄養塩モニタリングは技術的には可能であるが, 全国の水系に普及させることはメンテナンスも含めコス 卜面において現実的ではない. また，降雨出水時の現地 調査は危険が伴ううえに, 複数地点にわたる連続採水に は極めて多くの時間と労力を要する.

このような課題を踏まえ, 出水時を含めた物質輸送量 を簡便かつ連続的に算定する一手法として, 自動観測機 器によるモニタリング指標から栄養塩類の負荷量を推定 寸る試みがなされてきた7,8). しかしながら, 出水時の水 質データが不足しているため，大阪湾への流入河川にお いてその適用性について検討された例はない.

本研究では, 淀川本川とその上流三支川（桂川, 宇治 川, 木津川），大和川を対象に，平水時および出水時に 現地観測を実施し, 各河川の水質特性とその変動要因を 明らかにする. さらに, その解析結果を基に, 水質モ二 タリング指標を利用した物質輸送量の推定を試み，その 


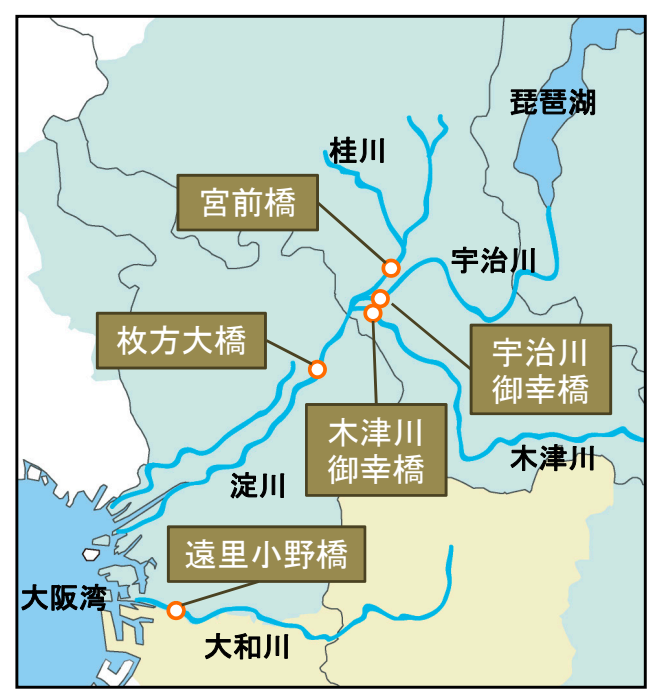

図-1 対象領域と観測地点

有用性について評価を行う.

\section{2. 対象領域の概要}

研究対象領域を図-1に示寸，淀川は琵琶湖から流出す る瀬田川（天ケ瀬ダムより下流では宇治川に名称を変え る）に加えて，桂川と木津川の三川が合流して形成され る河川であり，大阪平野を流下しながら神崎川と大川を 分流して大阪湾へ流入する. 桂川の上流域には山地が多 いが，下流域では市街地が形成されており，下流部での 河川流量は平水時には半分近くを下水処理水が占めてい る ${ }^{1)}$. 宇治川は琵琶湖から流出した後, 中流部において 天ケ瀬ダムを経由するため, 流量・水質ともに琵琶湖湖 水の影響を強く受ける9 とともに, ダム貯留の影響も受 けている. 木津川は流域内に山地・農地が多く, 一部下 水道が未整備の地域もあるが, 比較的人為的影響の小さ い河川である. 大和川は初瀬川を源流に, 奈良盆地と大 阪平野を流れ，大阪湾へ注ぐ一級河川である. 流域内の 都市化に伴い水質污濁が深刻化し, 近年の様々な環境施 策により水質は改善傾向にあるものの，一級河川の中で は依然として最低水準にある。

\section{3. 現地調査の概要}

出水時を含めた河川の水質特性を明らかにするために, 月1回の平水時調査と出水時の調查を継続して実施して いる.ここでは，淀川と上流三川については2009年4月 から2010年8月までに得られたデータを，また大和川に ついて 2009 年3月から2010年3月までのデータを基に解 析を行う。採水地点は，桂川では宮前橋（三川合流地点 から上流約 $2.4 \mathrm{~km}$ ），宇治川では宇治川御幸橋（同上流 約 $1.2 \mathrm{~km}$ ），木津川では木津川御幸橋（同上流約 $1.2 \mathrm{~km} ）$,
淀川本川では枚方大橋（同下流約 $9 \mathrm{~km}$ ，河口より上流約 $25.9 \mathrm{~km}$ ），大和川では遠里小野橋（河口より上流約 $4.2 \mathrm{~km}$ ）である（図-1）。なお，各観測地点では関係機 関により平水時に月1回の頻度で公共用水域水質調査が 実施されている、本研究では，筆者らの観測結果に加え て，2006年1月から2009年12月までに行われた公共用水 域水質調査の結果も解析に用いる.

橋上から流心において採水し, 水温, $\mathrm{pH}$, 電導度, 濁度を測定した後, 冷暗条件下で採水試料を実験室に持 ち帰り水質分析を行った. 分析項目は形態別の栄養塩

(N，P， Si） と有機炭素，およびSS，CODである. た だし，懸濁態成分（懸濁態窒素PN，懸濁態リンPP，有 機懸濁態炭素POC）については全成分と全溶存態成分と の差より算定した。現地測定にはpH-電導度計D54SE （HORIBA），電導度計SC82（YOKOGAWA）および 多成分水質計AAQ1183-H（JFEアドバンテック）を，水 質分析にはAACSV (BLTEC) およびTOC-V（島津製作 所）を使用した。 また，2009年10月台風18号に伴う出水 時に採水した試料については, 質量分析計Finnigan MAT252（Thermo Electron Corporation）を用いた水素・ 酸素安定同位体比 $\left(\delta \mathrm{D}, \delta^{18} \mathrm{O}\right)$ の分析もあわせて行った. 河川流量はH-Q関係より算定した．ただし，2009年台 風18号に伴い発生した出水の際は, 淀川合流部における 背水の影響により, 増水期から減水初期にかけてH-Q関 係が成り立たなかったため, 以下の方法により各上流支 川の流量を推定した。 まず, 高流量域まで適用可能な $\mathrm{H}-$ $\mathrm{Q}$ 式が得られている枚方地点については，H-Q式をその まま適用して流量を算定した。 ただし, 低流量時にはよ り精度の高い高浜地点におけるH-Q式を用いた. 次に, 保存性の高い水質指標 $\left(\delta^{18} \mathrm{O}\right.$, 水温, 電導度, $\mathrm{SiO}_{2}$ - $\mathrm{Si}$ 濃 度）の観測データを用いて, 各収支式より淀川への流量 比率を最小二乗法により推定し, 枚方地点の流量を乗じ ることにより各支川の流量を推定した.

\section{4. 河川の水質特性と変動要因の分析}

\section{（1）水質の流量依存性}

現地観測により得られた水質と流量の関係を図-2に示 す，その関係は溶存態成分と懸濁態成分で大きく異なっ

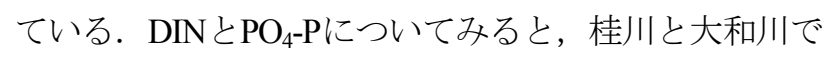
は濃度は低流量時には大きく変動するが, 流量の増加に 伴い収束する傾向がみられる. 一方, 宇治川や木津川で は濃度は流量に依存せず，概㱛一定值を示している。

ここで, 淀川・大和川流域における河川水中の塩化物 イオンはその大半が生活排水や工業廃水に由来し ${ }^{10,11)}$, かつ高い保存性を有することから, 河川水質に及ぼす点 源負荷の影響の大きさを表す指標として用いることがで きる. 図-3に塩化物イオン濃度の流量依存性を, 図-4に 塩化物イオン濃度と電導度の関係を示す（いずれも公共 

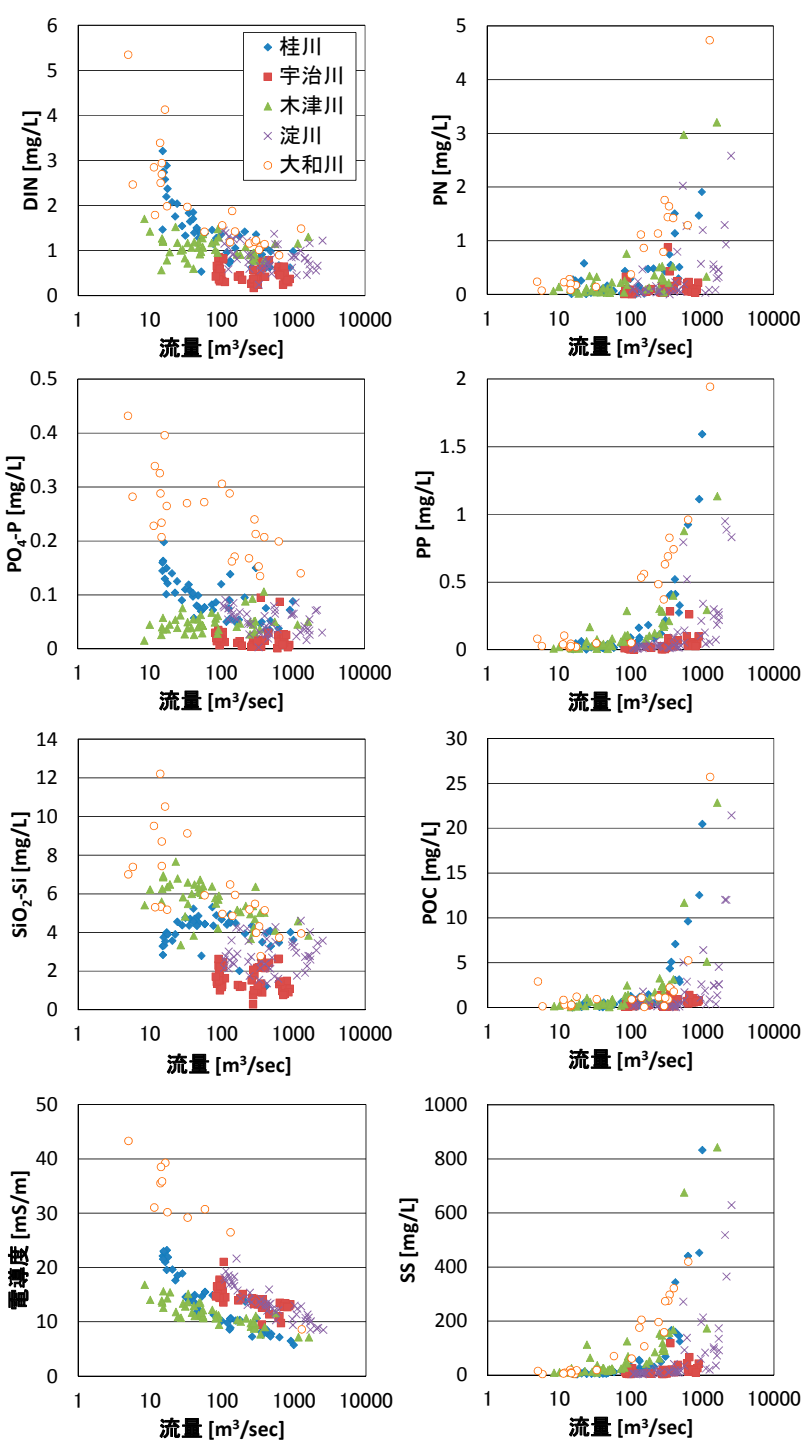

図-2 水質の流量依存性

用水域水質調査結果より作成）。桂川と大和川では塩化 物イオン濃度は低流量時に高い值を示し，平水時におけ る点源負荷の影響が宇治川や木津川に比べて大きいと言 える. 塩化物イオン濃度の流量依存性は図-2に示した $\mathrm{DIN}$ PO $\mathrm{PO}_{4}-\mathrm{P}$ 類似していることから，平水時の桂川と 大和川におけるDINと $\mathrm{PO}_{4}-\mathrm{P}$ は主に点源負荷に由来して いると推察できる。 また，図-4に示すように，塩化物イ オン濃度と電導度はほぼ一意の関係にあることから，電 導度も間接的に人為的負荷の影響を表す指標となってい るものと考えられる. 図-2に示した電導度の流量依存性 に注目すると，いずれの河川においても流量の増加に伴 い低下，収束しているが，その傾きや収束值は河川によ り異なり，流域の土地利用特性等に応じた流出特性の差 異が現れている. なお，宇治川で高流量時においても電 導度が高い值を示しているのは，供給される琵琶湖湖水

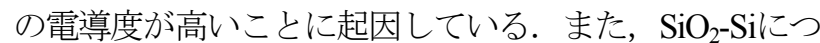
いても流量増加に伴い濃度が低下する傾向を示している が，桂川では低流量域で低い值がみられる，その原因と しては，河川自流量の低下に伴う低 $\mathrm{SiO}_{2}-\mathrm{Si}$ 濃度の下水処

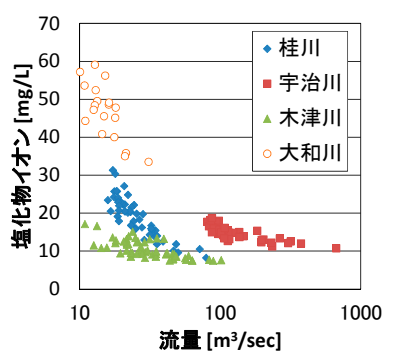

図-3 塩化物イオン濃度の 流量依存性

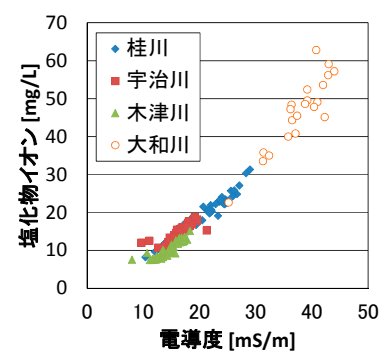

図-4 塩化物イオン濃度と 電導度の関係
理水の影響等が考えられるが，現時点ではその原因の特 定には至っていない.

一方，図-2において眯濁態成分は平水時に低い濃度を 示し, 流量の増加に伴い急激に上昇する傾向がみられる. ただし，宇治川の水質は高流量時にも濃度変化が小さく， 無機溶存態濃度が他河川に比べて低いこともあわせて考 えると，上流に位置する琵琶湖やダムにおける貯留や流 量制御の効果によって懸濁物質がトラップされているこ とが推察される12).

\section{（2）懸濁態成分と S Sの関係}

懸濁態成分はSSに含有または吸着して存在しているた め, 両指標には各河川の水環境に応じた関係が存在する と考えられる．観測結果から得られたSSと懸濁態成分の 負荷量の関係を図-5に示す。若干のバラツキはみられる ものの，いずれの河川においてもその関係は次の関数形 で概ね近似することが可能であった。

$$
L_{P M}=a \times L_{S S}^{b}
$$

ここで， $L_{P M}$ : 眯濁態負荷量 $(\mathrm{g} / \mathrm{sec}), L_{S S}: \mathrm{SS}$ 負荷量 $(\mathrm{g} / \mathrm{sec})$, $a, b$ : 係数である. 表-1に式中の係数および相関係数の 一覧を示す。一般に河川水中のPPは土砂粒子に吸着した 形態で多く存在しており ${ }^{3), 13)}$ ，本結果においてもSSと極 めて高い相関が得られた。一方で, PNやPOCは生物体 を主な起源としており，その動態には物理過程に加え生 物化学的過程が大きく関わるために相関が低下したと考 えられる. また，宇治川ではいずれの項目においても他 河川に比べて低い相関を示したが，琵琶湖やダムの貯留 によってSSに質的な変化が生じているものと考えられる.

\section{（3）無機溶存態成分と電導度の関係}

図-6に無機溶存態濃度と電導度の関係を示す. DINと $\mathrm{PO}_{4}-\mathrm{P}$ にいては観測結果に加え, 同観測地点における 公共用水域水質調査結果もあわせて示している. DINと $\mathrm{PO}_{4}-\mathrm{P}$ に注目すると, 桂川においてのみ電導度と高い相 関がみられる. 上記の通り, 平水時の桂川におけるDIN やPO 4 -Pは点源負荷を主な起源としている. また, 流域 内に市街地を広く抱える桂川では，雨天時に沈着した雨 水は排水溝等を通じて速やかに河道へ排出されるため, 降雨に伴う面源流出水中の溶存イオン濃度は他河川に比 して相対的に低いと考えられる.これは，図-2に示した 

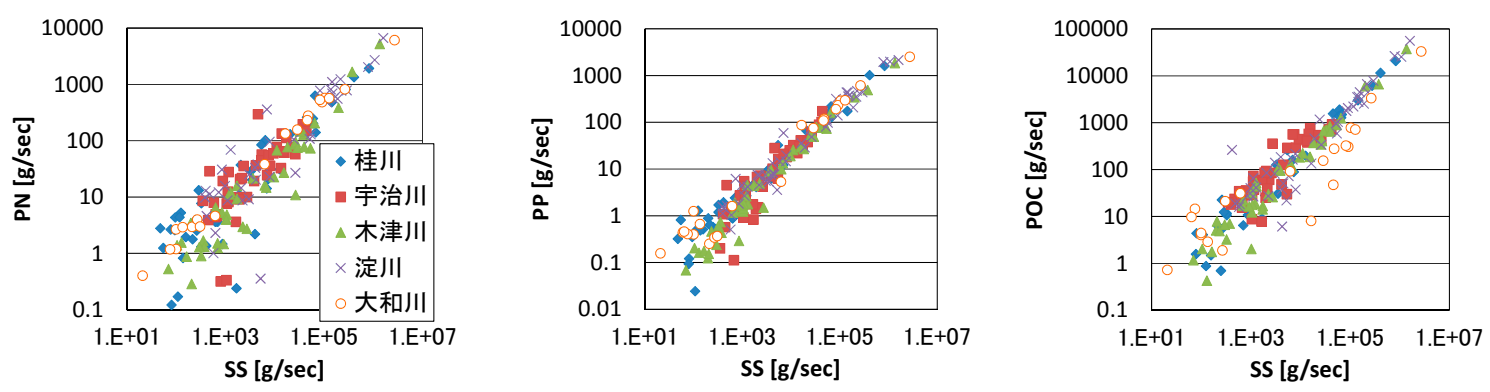

図-5 懸濁態負荷量とSS負荷量の関係
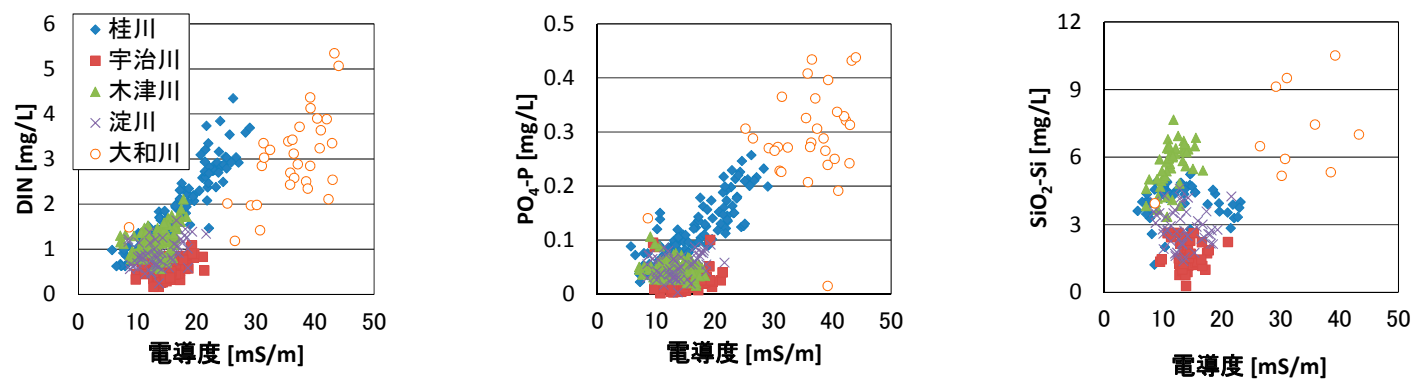

図-6 無機溶存態濃度と電導度の関係

電導度と流量の関係において，桂川における高流量時の 電導度が他の河川に比して低い值を示していることとも 一致する. すなわち，桂川における降雨時のDINと $\mathrm{PO}_{4^{-}}$ $\mathrm{P} の$ 濃度変動には，電導度の高い生活排水や工業廃水と 電導度の低い雨水との混合過程が支配的であり，その結 果，濃度と電導度の間に高い相関が得られたものと考え られる. また，これらの関係はそれぞれ以下に示すよう な線形関係で近似が可能であった。

$$
\begin{array}{ll}
C_{D I N}=0.134 \times E C-0.293 & \left(\mathrm{R}^{2}=0.84\right) \\
C_{P O 4-P}=0.00778 \times E C-0.00829 & \left(\mathrm{R}^{2}=0.71\right)
\end{array}
$$

ここで, $C_{D I N}: \mathrm{DIN}$ 濃度 $(\mathrm{mg} / \mathrm{L}), C_{P O 4-P}: \mathrm{PO}_{4}-\mathrm{P}$ 濃度 $(\mathrm{mg} / \mathrm{L})$, $E C:$ 電導度 $(\mathrm{mS} / \mathrm{m})$ である。また，大和川においても， 桂川と同様に河川水質に及ぼす点源負荷の影響が大きく, 電導度の低下に伴いDIN， $\mathrm{PO}_{4}$-P濃度も低下する傾向が みられる。しかし，既往の調査研究 ${ }^{14)}$ により，大和川流

\section{表-1 SS-懸濁態負荷量関係式の係数一覧と相関係数}

\begin{tabular}{|c|c|c|c|c|}
\hline 水質項目 & 河川名 & $a$ & $b$ & $R^{2}$ \\
\hline \hline \multirow{4}{*}{ PN } & 桂川 & $2.99 \times 10^{-2}$ & 0.796 & 0.79 \\
\cline { 2 - 5 } & 宇治川 & $2.66 \times 10^{-2}$ & 0.823 & 0.59 \\
\cline { 2 - 5 } & 木津川 & $1.07 \times 10^{-2}$ & 0.867 & 0.89 \\
\cline { 2 - 5 } & 淀川 & $3.30 \times 10^{-2}$ & 0.813 & 0.78 \\
\cline { 2 - 5 } & 大和川 & $3.61 \times 10^{-2}$ & 0.822 & 0.99 \\
\hline \multirow{4}{*}{ PP } & 桂川 & $3.63 \times 10^{-3}$ & 0.958 & 0.94 \\
\cline { 2 - 5 } & 宇治川 & $9.73 \times 10^{-4}$ & 1.09 & 0.84 \\
\cline { 2 - 5 } & 木津川 & $1.05 \times 10^{-3}$ & 1.05 & 0.97 \\
\cline { 2 - 5 } & 淀川 & $4.02 \times 10^{-3}$ & 0.940 & 0.96 \\
\cline { 2 - 5 } & 大和川 & $6.70 \times 10^{-3}$ & 0.895 & 0.96 \\
\hline \multirow{4}{*}{ POC } & 桂川 & $2.06 \times 10^{-2}$ & 1.01 & 0.94 \\
\cline { 2 - 5 } & 宇治川 & $6.20 \times 10^{-2}$ & 0.913 & 0.78 \\
\cline { 2 - 5 } & 木津川 & $1.25 \times 10^{-2}$ & 1.04 & 0.95 \\
\cline { 2 - 5 } & 淀川 & $3.83 \times 10^{-2}$ & 0.941 & 0.86 \\
\cline { 2 - 5 } & 大和川 & $1.50 \times 10^{-1}$ & 0.707 & 0.83 \\
\hline
\end{tabular}

域では下水道普及率が低く，排水の多くが家庭の小型浄 化槽で処理されているために，冬季には処理能力が低下 し河川水質が悪化するというメカニズムが明らかにされ ている.今回の結果においても平水時濃度には強い水温 依存性がみられ，大和川におけるDINやPO $\mathrm{PO}_{4} \mathrm{P}$ の濃度変 動は電導度のみから説明することはできなかった. 一方 で，木津川と宇治川ではDINおよび $\mathrm{PO}_{4}-\mathrm{P} の$ 濃度と電導 度に有意な相関はみられない。これは，両河川では平水 時水質に対する点源負荷の影響が桂川や大和川に比べて 小さいことに加え，宇治川の流出水は気象状況に依らず 琵琶湖湖水が大半を占めるために濃度の流量依存性が低 いこと，また農地や山地を多く抱える木津川では点源負 荷だけでなく雨天時の面源負荷も河川のDIN， $\mathrm{PO}_{4}-\mathrm{P}$ 濃 度に対する大きな変動要因であること等が原因として考

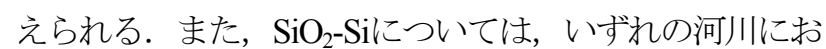
いても電導度との間に明確な相関はみられず, 自然循環 系，人口循環系に依らず保存性を示すことが示唆された.

\section{5．テレメータ指標を用いた物質輸送量の推定}

\section{(1) 解析概要}

淀川と上流三川では現地観測地点の付近に自動水質観 測所が設置されており, 濁度と電導度について毎時のテ レメータ観測がなされている。ここでは，2010年5月22 日から31日にかけて発生した出水イベントを対象に，前 章において得られた式(1)とテレメータによる濁度観測 データを利用して，出水時を含めた懸濁態負荷量の推定 を試みる. 同様に，溶存態成分についても，電導度との 間に良好な相関が得られた桂川のDINと $\mathrm{PO}_{4}-\mathrm{P} に$ 関して， テレメータ電導度と式(2)から負荷量の推定を行う。また, 


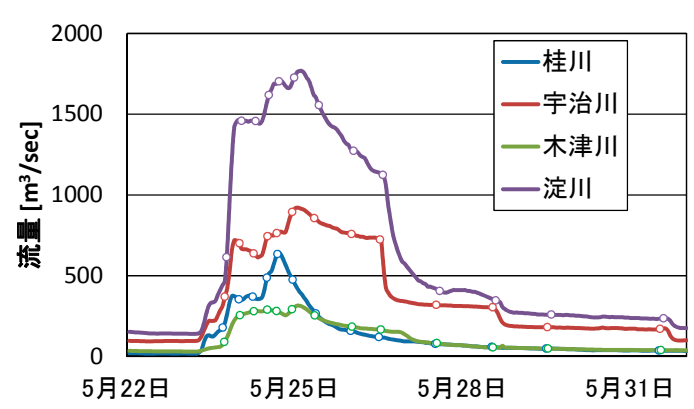

図-7 流量の経時変化

解析対象期間に実施した一連の現地観測結果との比較か ら，テレメータ指標を利用した物質輸送量の推定精度に ついて検証を行う.

テレメータでは濁度のモニタリングは行われているが, SS濃度は測定されていない. しかし, 両指標はいずれも 水中の濁りを表寸指標であるため，河川ごとに固有の関 係を有している，観測結果を基に両指標の関係を調べた ところ，いずれの河川においても良好な相関 $\left(\mathrm{R}^{2} \geqq\right.$ 0.93）が得られたため，今回はこの関係を用いて濁度か らSS濃度の換算を行った。 また，電導度や濁度は，検定 方法の違いや測定機種の特性により計測差が生じる可能 性が考えられるため, 各観測地点について, 採水試料の 現地測定值と採水時刻におけるテレメータ值との関係 （後掲の図-10）を求め，測定值の補正を行った.

\section{(2) 結果と考察}

解析対象期間における流量の経時変化を図一7に示寸. 図中の丸印は採水時刻を示しており，各観測地点につき 計13回の採水を行った. 今回の出水では宇治川流域で降 水量が多く, 淀川本川の流量は最大約 $1,800 \mathrm{~m}^{3} / \mathrm{sec}$ に達し た. なお，宇治川では瀬田川洗堰や天ケ瀬ダムにおける 放流水量の調節操作により, 減水期に急激な流量変化が 生じ，下流の淀川本川にもその影響が及んでいた。この ように，淀川の流出特性は降雨パターンだけでなく，人 為的な要因にも大きく影響されている.

懸濁態負荷量について，採水分析による実測值と推定 值との比較を図-8に示す，宇治川と木津川においては， いずれの水質項目についても比較的良好な精度で負荷量 を推定することが可能であった。一方，桂川ではPPにつ いては同様に推定が可能であったものの，PNやPOCに ついては低流量域におけるSS との相関の低下のため, 実 測值から大きく乘離する結果となった。また，淀川本川 では上流三川に比べると概して推定精度は低い。これは, 上流域の降雨パターンに応じて上流三川からの負荷量寄 与が異なるためと考えられる. 一方，図-9に示寸ように， 桂川においてテレメータの電導度からDIN， $\mathrm{PO}_{4}-\mathrm{P}$ の負 荷量を推定したところ，その誤差はそれぞれ約 $10 \%$ ，約 30\%の範囲にとどまり, 極めて高い精度で推定すること が可能であった.

懸濁態成分とSSの負荷量について高い相関関係が得ら
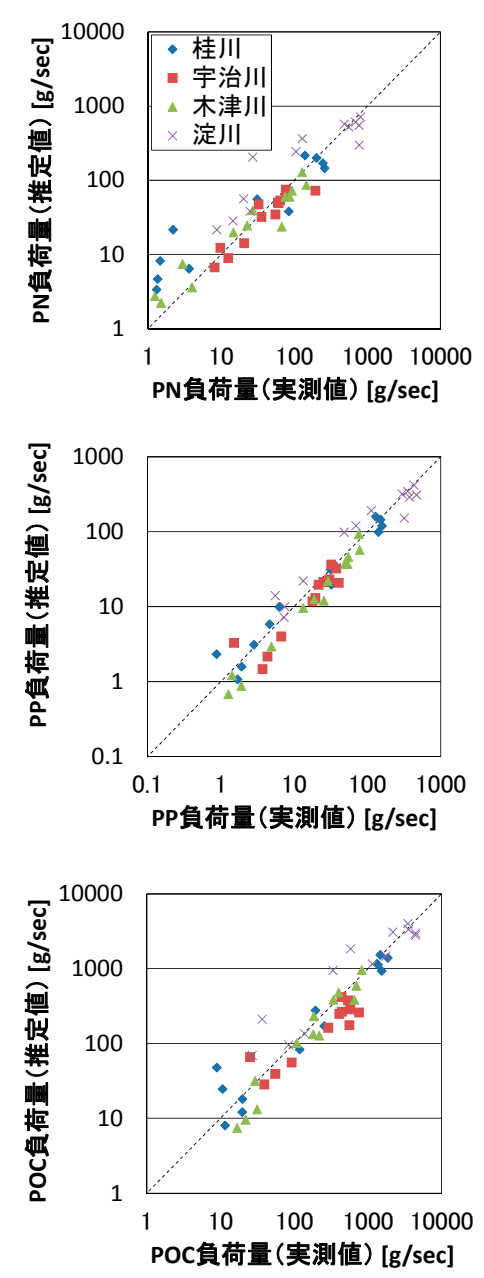

図-8 実測値と推定値の比較（懸濁態成分）
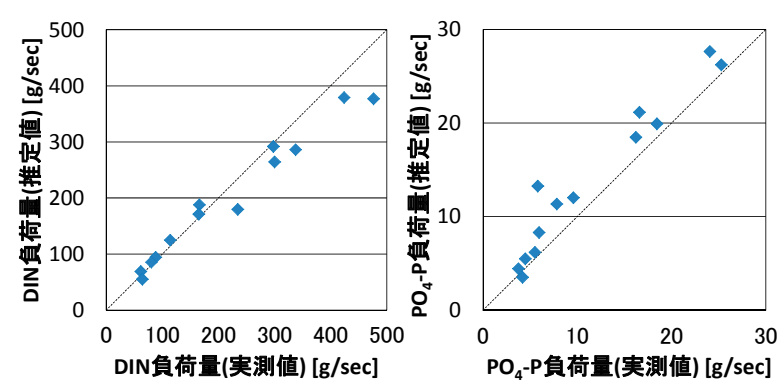

図-9 実測值と推定值の比較（無機溶存態成分）
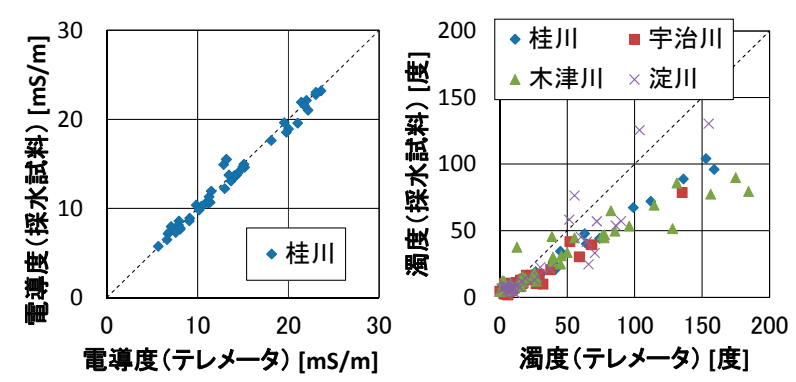

図-10 採水測定値とテレメータ観測值の比較 
れたにも拘わらず，テレメータ濁度を用いた負荷量推定 では精度が低下する場合がみられた，濁度と電導度につ いて，採水試料の現地測定值と採水時刻におけるテレ メータ観測值の比較を図-10に示す．いずれの関係につ いても相関係数は $\mathrm{R}^{2} \geqq 0.84$ と高い值が得られたものの, 濁度に注目寸ると木津川や淀川において大きなばらつき が生じていることがわかる，これは，採水調査は河川の 流心で行っている一方で, テレメータ観測は河岸で取水 しているため，採水地点の上流側における支川の合流や 下水処理水の放流，または河道形状によって横断方向に 水質変化している場合には，採水調査とテレメータ観測 で不一致が生じるためと考えられる. 今回の推定結果に はこうしたテレメータ機器の設置場所に起因する誤差も 含まれており, テレメータ指標を用いた物質輸送量の推 定精度は, 自動水質観測データの河川横断面の水質代表 性によっても大きく左右されることが示された.

\section{6. おわりに}

本研究では，淀川本川とその上流三川（桂川，宇治川， 木津川）および大和川を対象に現地観測を実施し，各河 川の水質特性とその変動要因について解析を行った. ま た，既設の水質テレメータ指標を利用した物質輸送量の 推定を試み，その有用性について検証を行った.

本研究で得られた主たる結論は以下の通りである.

(1) 出水時を含めた観測結果から, 無機溶存態濃度は流 量の増加に伴い低下寸るが，一方で懸濁態濃度は急激に 上昇する傾向がみられた．また，電導度とSSはそれぞれ 無機溶存態成分およひ䀣濁態成分と同様の流量依存性を 示した.

(2) 桂川と大和川において, 塩化物イオン濃度とDIN, $\mathrm{PO}_{4}-\mathrm{P}$ 濃度はいずれも低流量時に高く, 河川水中のDIN と $\mathrm{PO}_{4}-\mathrm{P}$ は主に点源負荷に由来していると考えられた。

(3) 桂川において，DIN， $\mathrm{PO}_{4}-\mathrm{P}$ 濃度と電導度にはそれぞ れ有意な線形関係が見出された，また，出水時を含めた 桂川のDIN, $\mathrm{PO}_{4}-\mathrm{P}$ 濃度は, 点源負荷と雨水の混合過程 によって概ね決定されることが示唆された.

(4) さらに，桂川について得られた関係を基に，テレ メータ電導度からDIN と $\mathrm{PO}_{4}-\mathrm{P}$ 負荷量を算定したとこ ろ，その推定誤差はそれぞれ約10\%，約30\%にとどまり， 極めて良好な精度で推定が可能であった。

(5) 懸濁態成分とSSの負荷量は概衩良好な相関を有し, 得られた関係式を基にテレメータ濁度から懸濁態負荷量 を算定したところ，いずれの河川においても比較的良好 な精度で推定することが可能であった．ただし，桂川と 淀川では相関の低下により，PN，POC負荷量の推定は 困難であった.
（6）テレメータ指標を用いた物質負荷量の推定精度は, テレメータの設置場所の水質代表性にも大きく影響され ることがわかった.

謝辞 : 本研究の一部は, 科学研究費補助金（基盤研究 (B) No.21360236）および財団法人大林都市研究振興財団 により補助を受けて行われた．また，分析に際しては京 都大学生態学研究センターの共同利用施設（安定同位体 比質量分析計）を使用させていただいたとともに，淀川 河川事務所並びに大和川河川事務所には水位データの提 供等のご高配をいただいた．ここに，あわせて感謝の意 を表する次第である.

\section{参考文献}

1) 大垣眞一郎 監修: 河川と栄養塭類，技報堂出版，2005.

2) 坂井文子, 二瓶泰雄 他 : 江戸川・荒川・玉川・中川におけ る出水時栄養塩 $\cdot \mathrm{COD}$ 負荷特性, 水工学論文集, 第52巻, pp.1117-1122, 2008.

3) 田中勝久, 豊川雅哉 他 : 土壌流出によるリン負荷の沿岸環 境への影響, 沿岸海洋研究, 第40巻, pp.131-139, 2003.

4) 西田修三, 中谷祐介 他 : 大阪湾の水質と一次生産に及ぼす 降雨の影響, 水工学論文集, 第52巻, pp.1345-1350, 2008.

5) 中谷祐介, 西田修三: 淀川・大和川における出水時負荷特 性と陸域流入負荷の評価，水工学論文集、第54巻、pp.1615$1620,2010$.

6) 西田修三, 前田瑛美, 今岡知武: 淀川水系の出水特性と物 質輸送の解析，河川技術論文集，第16巻，pp.317-322， 2010.

7) 山本浩一, 二村貴幸 他: 濁度計による䀣濁態栄養塩負荷推 定に関する研究，河川技術論文集，第9巻，pp.515-520，2003.

8) 城戸由能, 福田勝之, 中北英一: 自動水質計を用いた雨天 時を含む河川水質濃度の推定と負荷量算定評価, 水工学論文 集, 第54巻, pp.1387-1392, 2010.

9) 和田英太郎 監修: 流域環境学, 京都大学学術出版会, 2009. 10) 海老瀬潜一: 桂・宇治・木津川と淀川本川の塩化物イオン 収支の一考察, 水環境学会誌, Vol.32, pp.441-449, 2009.

11）窪原拓馬, 井伊博行 他: 大和川流域に执ける河川水の水 質特性について, 水工学論文集, 第45巻, pp.985-990, 2001.

12) Harashima, A. et al. : Verification of the Silica Deficiency Hypothesis Based on Biogeochemical Trends in the Aquatic Continuum of Lake Biwa - Yodo River - Seto Inland Sea, Japan, Ambio, Vol.35, pp.36-42, 2006.

13) 西田修三，中谷祐介 : 淀川河口域における河川懸濁物質の リン吸着特性, 海岸工学論文集, 第54巻, pp.1101-1105, 2007.

14) 井伊博行, 谷口正伸 他 : 大和川のBOD, アンモニア態窒 素, 陰イオン界面活性剤濃度の季節変動とその原因について, 水工学論文集, 第46巻, pp.235-240, 2002.

(2010. 9. 30受付) 